University of Nebraska - Lincoln

DigitalCommons@University of Nebraska - Lincoln

Nebraska Game and Parks Commission -- Staff

Research Publications

Nebraska Game and Parks Commission

2011

Ecosystem services provided by playas in the High Plains: potential influences of USDA conservation programs

\author{
Loren M. Smith \\ Oklahoma State University - Main Campus, loren.smith@okstate.edu \\ David A. Haukos \\ U.S. Fish and Wildlife Service \\ Scott T. McMurry \\ Oklahoma State University - Main Campus \\ Ted LaGrange \\ Nebraska Game and Parks Commission \\ David Willis \\ Clemson University
}

Follow this and additional works at: https://digitalcommons.unl.edu/nebgamestaff

Part of the Environmental Sciences Commons

Smith, Loren M.; Haukos, David A.; McMurry, Scott T.; LaGrange, Ted; and Willis, David, "Ecosystem services provided by playas in the High Plains: potential influences of USDA conservation programs" (2011). Nebraska Game and Parks Commission -- Staff Research Publications. 53.

https://digitalcommons.unl.edu/nebgamestaff/53

This Article is brought to you for free and open access by the Nebraska Game and Parks Commission at DigitalCommons@University of Nebraska - Lincoln. It has been accepted for inclusion in Nebraska Game and Parks Commission -- Staff Research Publications by an authorized administrator of DigitalCommons@University of Nebraska - Lincoln. 


\title{
Ecosystem services provided by playas in the High Plains: potential influences of USDA conservation programs
}

\author{
Loren M. Smith, ${ }^{1,5}$ David A. Haukos, ${ }^{2}$ Scott T. McMurry, ${ }^{1}$ Ted LaGrange, ${ }^{3}$ and David Willis ${ }^{4}$ \\ ${ }^{1}$ Department of Zoology, Oklahoma State University, Stillwater, Oklahoma 74078 USA \\ ${ }^{2}$ U.S. Fish and Wildlife Service, Texas Tech University, P.O. Box 42125, Lubbock, Texas 79409 USA \\ ${ }^{3}$ Nebraska Game and Parks Commission, 2200 North 33rd Street, P.O. Box 30370, Lincoln, Nebraska 62503-0370 USA \\ ${ }^{4}$ Department of Applied Economics and Statistics, Clemson University, Clemson, South Carolina 29634 USA
}

\begin{abstract}
Playas are shallow depressional wetlands and the dominant wetland type in the non-glaciated High Plains of the United States. This region is one of the most intensively cultivated regions in the Western Hemisphere, and playas are profoundly impacted by a variety of agricultural activities. Conservation practices promoted through Farm Bills by the U.S. Department of Agriculture (USDA) that influence playas and surrounding catchments impact ecosystem functions and related services provided by wetlands in this region. As part of a national assessment, we review effects of agricultural cultivation and effectiveness of USDA conservation programs and practices on ecosystem functions and associated services of playas. Services provided by playas are influenced by hydrological function, and unlike other wetland types in the United States, hydrological function of playas is impacted more by accumulated sediments than drainage. Most playas with cultivated catchments have lost greater than $100 \%$ of their volume from sedimentation causing reduced hydroperiods. The Conservation Reserve Program (CRP) has the largest influence on playa catchments (the High Plains has $>2.8$ million ha), and associated sedimentation, of any USDA program. Unfortunately, most practices applied under CRP did not consider restoration of playa ecosystem function as a primary benefit, but rather established dense exotic grass in the watersheds to reduce soil erosion. Although this has reduced soil erosion, few studies have investigated its effects on playa hydrological function and services. Our review demonstrates that the Wetlands Reserve Program (WRP) has seldom been applied in the High Plains outside of south-central Nebraska. However, this is the primary program that exists within the USDA allowing conservation practices that restore wetland hydrology such as sediment removal. In addition to sediment removal, this practice has the greatest potential effect on improving hydrologic function by reducing sedimentation in vegetative buffer strips. We estimate that a 50-m nativegrass buffer strip could improve individual playa hydroperiods by up to 90 days annually, enhancing delivery of most natural playa services. The potential for restoration of playa services using USDA programs is extensive, but only if WRP and associated practices are promoted and playas are considered an integral part of CRP contracts.
\end{abstract}

Key words: conservation programs; High Plains, USA; hydroperiod; playas; sediment; wetlands.

\section{INTRODUCTION}

The non-glaciated High Plains of the United States extend from Texas and New Mexico in the south to Nebraska and Wyoming in the north (Fig. 1). This largely semiarid region was primarily short-grass prairie, although mixed-grass and tall-grass prairie occurred in isolated eastern areas (Küchler 1975). These grasslands are considered some of the most endangered ecosystems in North America due to extensive cultivation (Samson and Knopf 1994). Native short-grass prairie has declined by at least $80 \%$ in Texas, while $77 \%$ of the mixed-grass prairie in Nebraska has been cultivated

Manuscript received 23 June 2009; revised 20 July 2009; accepted 22 July 2009. Corresponding Editor: J. S. Baron. For reprints of this Special Issue, see footnote 1, p. S1.

${ }^{5}$ E-mail: loren.smith@okstate.edu
(Samson and Knopf 1994:419). Any wetland system occurring in the High Plains has been heavily impacted by agriculture (Bolen et al. 1989).

As a result of extensive cultivation and other agriculture activities (e.g., confined-animal feeding operations, intensive livestock grazing), the High Plains is heavily influenced by U.S. Department of Agriculture (USDA) production agriculture and conservation title programs established by various Farm Bills (USDA 2009). Recently, the Natural Resources Conservation Service (NRCS) within USDA initiated the Conservation Effects Assessment Project (CEAP) to examine the influence of conservation programs and practices on environmental outcomes with wetland ecosystems identified as a key component of the overall evaluation (Eckles 2011). Although there are some riverine and depressional discharge wetlands in the High Plains, primarily in the Central and Northern High 


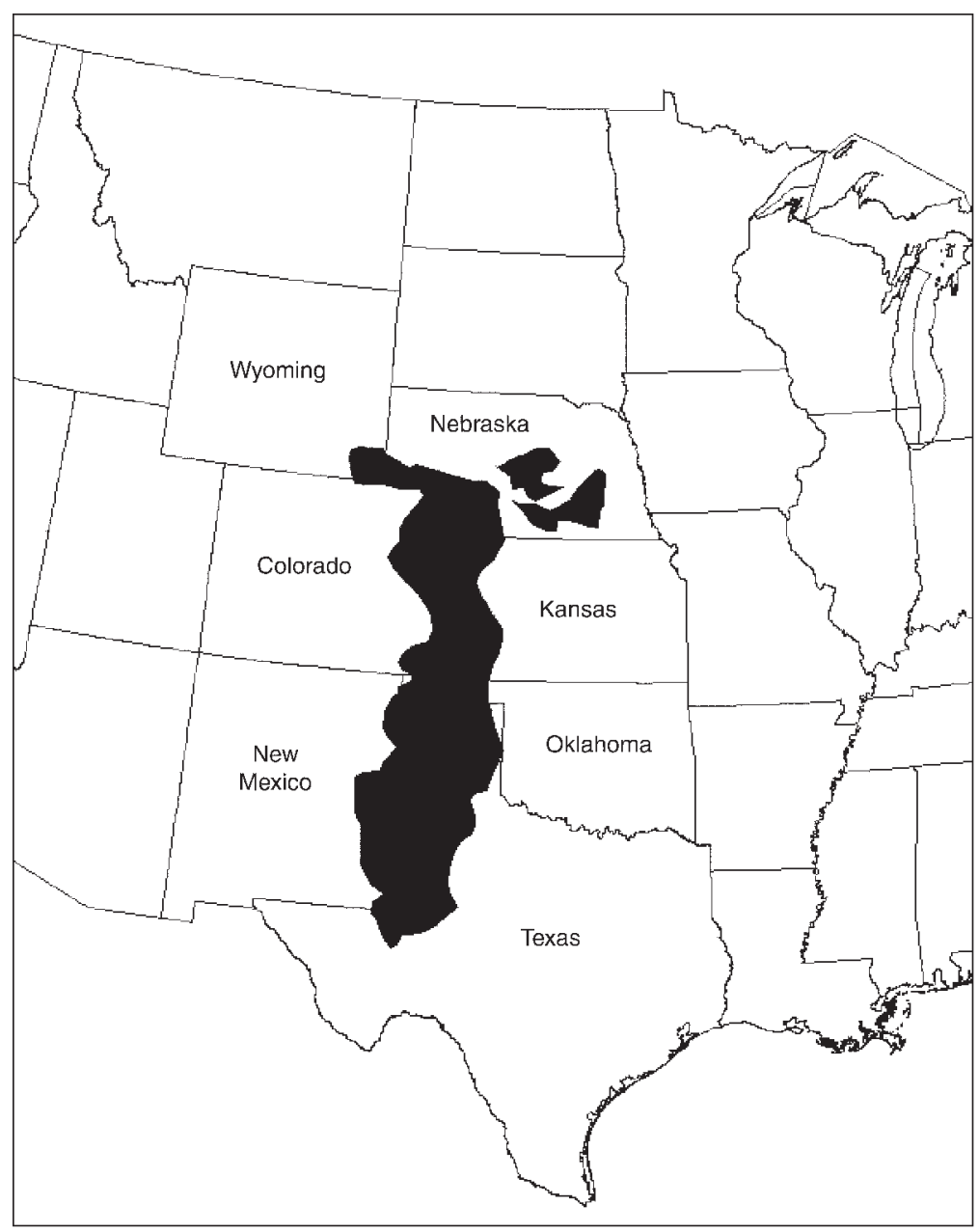

FIG. 1. The High Plains region containing playas in the United States.

Plains, the vast majority are depressional recharge wetlands, termed playas. As an example of the importance of these wetlands on the landscape, playas historically have conservatively covered $>120000$ ha of the Texas High Plains alone, with individual wetland area ranging from $<1$ ha to $>300$ ha (Haukos and Smith 1994). Estimates of the number of historical playas for the entire region range from 25000 to 50000 , variously based on the presence of hydric soils on soil maps, topographic maps, National Wetland Inventory maps, satellite imagery, and aerial photo coverage (e.g., Guthery et al. 1981, Sabin and Holliday 1995; Playa Lakes Joint Venture 2007, available online). ${ }^{6}$ Because of their geographic coverage and numbers in an area extensively influenced by USDA programs, High Plains playas were identified as key systems for inclusion in the national CEAP-Wetlands assessment. As part of the national synthesis, our paper (1) summarizes key ecosystem features of playas, (2) reviews the state of

${ }^{6}\langle$ http://pljv.org $/\rangle$ our knowledge on the effects of agricultural impacts on ecosystem functions of playas and their associated services, (3) documents application of USDA conservation programs and practices relative to playas, (4) examines potential effects of conservation practices on playa function and services, and (5) identifies emerging issues that will impact future delivery of playa services.

High Plains Playas: Related Functions and Services

The original short-grass prairie, and catchments of most playas in the High Plains, was dominated primarily by gramas (Bouteloua spp.) and buffalo grass (Buchlö̈ dactyloides), with relatively less coverage of wheatgrasses (Agropyron spp.), three-awns (Aristida spp.), prickly pear (Opuntia spp.), yucca (Yucca spp.), and broadleaved forbs (Küchler 1975; see Plate 1). The region of south-central Nebraska primarily was comprised of mixed grasses including bluestems (Andropogon spp.), wheatgrasses, and needle grass (Stipa spp.) (Küchler1975). In the extreme eastern portions of south-central Nebraska, plant communities included bluestems, switchgrass (Panicum virgatum), and Indian 


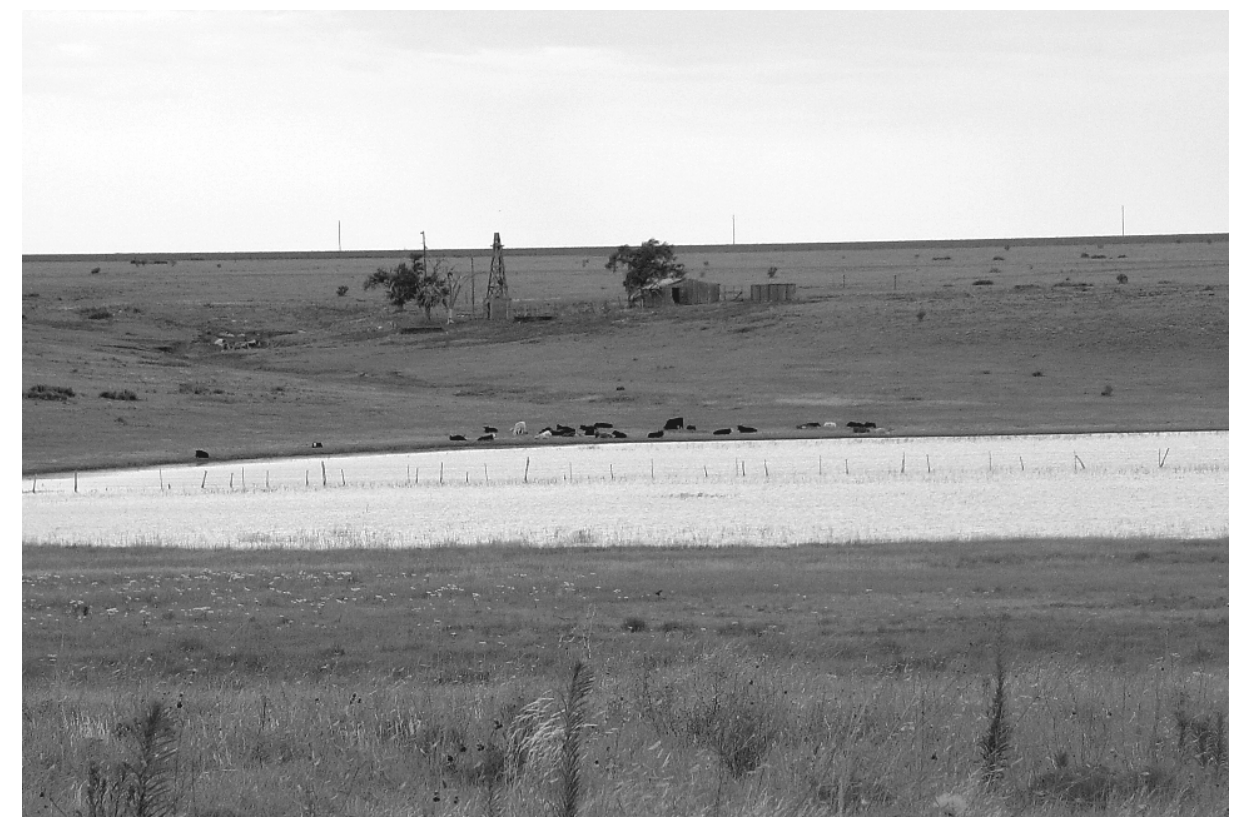

Plate 1. A playa with a native short-grass prairie watershed in the Texas High Plains, USA. Photo credit: L. M. Smith.

grass (Sorghastrum nutans). Playa catchments are now dominated by cotton agriculture in the Southern High Plains (eastern New Mexico and northwestern Texas), while wheat, corn, and soybean production dominates catchments in the northern portions of the region (Smith 2003). Intensive livestock grazing occurs in wetlands and catchments throughout the High Plains (Smith 2003).

Playas are hydrogeomorphically defined as shallow, depressional recharge wetlands, each existing in their own watershed or catchment (Smith 2003:6). Compared to other inland freshwater wetlands, the physical structure and hydrology of playas are relatively simple (e.g., Fennessy and Craft 2011). Playas only receive water from precipitation and catchment runoff, with water loss via evapotranspiration and recharge of the underlying aquifer. Playas within this region are further classified as palustrine seasonal or temporary wetlands (Cowardin et al. 1979) with their hydrology dictated by stochastic precipitation events. They were formed and maintained through a combination of dissolution of the underlying substrate, wind, and wave action (Osterkamp and Wood 1987, Kuzila 1994, Gustavson et al. 1995, Reeves and Reeves 1996).

The hydrology of depressional wetlands drives their functional attributes and the services they can provide (Euliss et al. 2008, Smith et al. 2008). As depressional wetlands, they have a critical floodwater attenuation service (NRC 1995:35). Estimates of historic water storage potential in playas exist for the Southern High Plains, and although estimates vary based on predicted numbers of playas, all are of substantial volume (Grubb and Parks 1968, Grubb et al. 1968, U.S. Department of Interior 1982). The U.S. Department of Interior (1982) estimated $6.6 \times 10^{8} \mathrm{~m}^{3}$ of water storage in the Southern
High Plains, and these historical projections are considered to be nominal given the conservative number of playas used to generate estimates. Playas are focus points of recharge to the Ogallala Aquifer, the largest in North America (Wood and Osterkamp 1987, Wood et al. 1997). In the Southern High Plains playas may be the only sites of recharge (Nativ and Riggio 1989, Stone 1990). Although the total volume of water recharged to the aquifer through playas is unknown, Wood et al. (1997) estimated a total regional annual average recharge of $11 \mathrm{~mm} / \mathrm{yr}$. Playas and their catchments are also assumed to provide water quality improvement services (Haukos and Smith 2003).

Extensive conversion of former prairie systems to agriculture has resulted in playas being the only remaining natural habitats supporting biodiversity provisioning in most areas (Bolen et al. 1989, Haukos and Smith 1994). The value of playas to biodiversity can be realized on several spatial scales: individual playa, surrounding watershed (e.g., cropland, grassland, and Conservation Reserve Program) regions, or the entire High Plains. For example, plant richness varies from 19 plant species for individual playas, 43 species at county levels, and 100 species in regions defined by similar vegetation communities, to nearly 350 for the entire Southern Great Plains (Haukos and Smith 2004). In the case of migratory birds, playas are vital for the maintenance of biodiversity in the Western Hemisphere (Haukos and Smith 1994). Because playas often provide the only aquatic habitat in the semiarid High Plains, a playa can increase biodiversity by over $300 \%$ of that same area of short-grass prairie not containing a playa (Smith 2003). Playas can store substantial amounts of plant biomass, ranging from 200 to $20000 \mathrm{~kg} / \mathrm{ha}$, 
leading to carbon sequestration and climate change amelioration (Smith 1988, 2003, Anderson and Smith 2002). The amount of carbon stored in playa soils is unknown, but thought to be low ( $<2 \%$; Luo 1994).

\section{Agricultural Impacts on Playa Function}

Because hydrology is the primary driver influencing most natural functions in wetlands (Euliss et al. 2008), any agricultural influence on hydrology will likely alter the magnitude of ecosystem service delivery. Crop cultivation in playa catchments causes unsustainable soil erosion that is deposited in the wetland via water transport (Luo et al. 1999). Although capture and retention of sediment is often listed as a wetland ecosystem service by reducing loads in streams and rivers (e.g., NRC 1995), it causes negative consequences to depressional wetland function (Smith et al. 2008). On average, playas with cropland watersheds in the Southern High Plains have lost $>100 \%$ of their hydric soil-defined volume (Luo et al. 1997). Because most playas have watersheds impacted by cultivation, the effects of sediment deposition occur throughout the High Plains. Unlike most other regions in the United States where deliberate drainage has been the primary cause of altered wetland hydrology (this issue; e.g., De Steven and Lowrance 2011, Fennessy and Craft 2011, Gleason et al. 2011), sedimentation is considered the primary threat to natural playa hydrology in all current and proposed conservation plans (e.g., Haukos and Smith 2003, LaGrange 2005).

Other threats to playa integrity include construction of drainage pits in the wetland and the surrounding watershed, land leveling, road construction, direct cultivation of the wetland, invasive species, urban expansion, lack of proper grazing management, and accumulation of contaminants such as pesticides from agricultural activities in the watershed (Haukos and Smith 2003). The region has the highest density of confined-animal feedlots in North America (Nebraska Department of Agriculture 2006; USDA National Agricultural Statistics Service, available online). ${ }^{7}$ High Plains' wetlands have been frequently incorporated into beef and dairy feedlot operations and often receive animal waste (Irwin et al. 1996). Because of extensive agricultural influences, other processes important in the maintenance of wetland structure and function have been greatly reduced. Historically, fire occurred with a frequency of once every 5 to 10 years in the region (Wright and Bailey 1982), but its occurrence has now been greatly reduced. Periodic seasonal herbivory by native herbivores such as bison (Bison bison) and elk (Cervus elaphus) has been eliminated.

Because sediment accumulation has been identified as the primary threat to ecosystem integrity in playas, most recent studies have included examination of the effect of

\footnotetext{
${ }^{7}\langle$ www.nass.usda.gov〉
}

this consequence of agricultural production on metrics associated with playa functions. Functional comparisons have primarily been between playas with cropland catchments vs. those with native-grassland catchments. Because most cropland playas have $>100 \%$ of their hydric soil-defined volume filled with sediment, much of the water previously stored within the wetland is displaced onto adjacent upland soils over a greater surface area and more permeable upland soils (Luo et al. 1997). The larger surface area reduces wetland floodwater storage service and results in greater evaporative losses (Tsai et al. 2007). Although the negative effect of cultivation is clear for floodwater storage, the effects on aquifer recharge and water quality remain uncertain. For example, although evaporative losses may be greater in cropland playas, cumulative recharge to the aquifer may be greater as a result of coarser sediments mixing with the hydric soil, creating more permeable pathways for infiltration within the wetland. Evaluating the impact of sediment accumulation on hydroperiod length, following decades of deposition, will have important implications for recharge estimates and modeling the effects of conservation practices on recharge (e.g., Euliss et al. 2011). Despite the potential for altered playas to accumulate contaminants and nutrients from cultivated watersheds, few studies have surveyed contaminant and nutrient levels relative to agricultural effects on the water quality improvement service (Thurman et al. 2000, Venne et al. 2006, 2008).

Reduced hydroperiod lengths affect all biotic community functions, altering support for biodiversity and carbon stores (Smith 2003). For example, plant communities in cropland playas that harbor greater sediment loads than grassland playas have increased numbers of exotics and annuals, which directly influences primary production (Smith and Haukos 2002, Haukos and Smith 2004, 2006). Throughout much of the High Plains, accumulation of sediment will reduce wetland depth and duration, resulting in increasing occurrence of xeric plant communities, which have lower production than moist-soil and aquatic communities.

Relative to biodiversity provisioning, reproduction and early development of amphibians are intimately linked to playas. For example, relative density of spadefoot toad (Spea multiplicata and S. bombifrons) metamorphs was found to be greater in cropland playas, while density of tiger salamanders (Ambystoma tigrinum) was lower in the same playas when compared to playas with native-grassland watersheds (Gray et al. 2004, Ghioca and Smith 2008, Ghioca-Robrecht and Smith 2008). Because salamanders are a top predator in the system, their absence alters the entire trophic structure of playas (Ghioca-Robrecht et al. 2009). Body size and immune function of amphibians in cropland playas are typically less than those of grassland playas (Gray and Smith 2005, McMurry et al. 2009). Sediments also bury invertebrate egg banks and, although they represent the highest faunal diversity, the direct effect of sediments on 
TABLE 1. Total number of specific U.S. Department of Agriculture (USDA) conservation program sites and number of conservation practices applied within each program in the High Plains, USA, by state, established from 2000 to 2006.

\begin{tabular}{|c|c|c|c|c|c|c|c|c|c|c|c|c|}
\hline \multirow[b]{3}{*}{ State } & \multicolumn{10}{|c|}{ Conservation program } & & \\
\hline & \multicolumn{2}{|c|}{ CRP } & \multicolumn{2}{|c|}{ CREP } & \multicolumn{2}{|c|}{ EQIP } & \multicolumn{2}{|c|}{ WHIP } & \multicolumn{2}{|c|}{ WRP } & \multicolumn{2}{|c|}{ Total } \\
\hline & $\begin{array}{l}\text { Sites } \\
\text { (no.) }\end{array}$ & $\begin{array}{l}\text { Practices } \\
\text { (no.) }\end{array}$ & $\begin{array}{l}\text { Sites } \\
\text { (no.) }\end{array}$ & $\begin{array}{l}\text { Practices } \\
\text { (no.) }\end{array}$ & $\begin{array}{l}\text { Sites } \\
\text { (no.) }\end{array}$ & $\begin{array}{l}\text { Practices } \\
\text { (no.) }\end{array}$ & $\begin{array}{l}\text { Sites } \\
\text { (no.) }\end{array}$ & $\begin{array}{l}\text { Practices } \\
\text { (no.) }\end{array}$ & $\begin{array}{l}\text { Sites } \\
\text { (no.) }\end{array}$ & $\begin{array}{l}\text { Practices } \\
\text { (no.) }\end{array}$ & $\begin{array}{l}\text { Sites } \\
\text { (no.) }\end{array}$ & $\begin{array}{c}\text { Practices } \\
\text { (no.) }\end{array}$ \\
\hline Colorado & 1720 & 4218 & 0 & 0 & 1128 & 4233 & 41 & 88 & 4 & 20 & 2893 & 8559 \\
\hline Kansas & 2268 & 7600 & 0 & 0 & 1332 & 5253 & 55 & 112 & 2 & 3 & 3657 & 12968 \\
\hline Nebraska & 6577 & 25400 & 17 & 69 & 8060 & 22469 & 246 & 596 & 115 & 400 & 15015 & 48934 \\
\hline New Mexico & 133 & 283 & 0 & 0 & 887 & 1970 & 3 & 5 & 0 & 0 & 1023 & 2258 \\
\hline Oklahoma & & 471 & 0 & 0 & & 996 & & 17 & 0 & 0 & & 1484 \\
\hline Texas & 226 & 4094 & 0 & 0 & 266 & 10671 & 5 & 160 & 0 & 0 & 497 & 14925 \\
\hline Total & 10924 & 42066 & 17 & 69 & 11673 & 45592 & 350 & 978 & 121 & 423 & 23085 & 89128 \\
\hline
\end{tabular}

Note: Abbreviations are: CRP, Conservation Reserve Program; CREP, Conservation Reserve Enhancement Program; EQIP, Environmental Quality Incentives Program; WHIP, Wildlife Habitat Incentives Program; and WRP, Wetland Reserve Program. Ellipses indicate missing data.

invertebrate community composition has not been studied in playas.

Playas are the principal site of nature-based recreation on the High Plains, with avian communities being the foremost attraction (Haukos 1994). In addition to providing critical habitat for migratory birds, playas supply a diversity of habitats supporting nesting and wintering bird species. Migratory birds connect playa habitats with others in the Western Hemisphere (e.g., Haukos et al. 2006) and, as such, agricultural impacts on wetlands of the High Plains negatively influence human recreation and subsistence in regions much removed from the High Plains. Playas with shorter hydroperiods due to accumulated sediments have lower avian diversity than those with longer hydroperiods (Tsai 2007). During wet years, when playas hold water for a longer period, survival of waterfowl wintering in playas is increased and exceeds estimates of other major wintering areas (Bergan and Smith 1993, Moon and Haukos 2006). Sediment accumulation, which causes shorter hydroperiods, affects not only biodiversity provisioning, but also wildlife-related human recreation on the High Plains and beyond.

\section{Application of USDA Conservation Programs AND PRActices}

We surveyed USDA data available since 2000 to determine application of the various programs for conservation available for landowners in the High Plains (Table 1). Conservation practices from five programs have been implemented on 23085 sites spread across the High Plains. Programs include the Environmental Quality Incentives Program (EQIP), Wildlife Habitat Incentives Program (WHIP), Wetlands Reserve Program (WRP), Conservation Reserve Program (CRP), and Conservation Reserve Enhancement Program (CREP). CRP and EQIP are the dominant programs implemented throughout the High Plains, accounting for nearly $98 \%$ of the total sites since 2000 (Table 1). Unfortunately, with the exception of WRP
( $1.5 \%$ of sites and $1.1 \%$ of practices; primarily in Nebraska), no program targeted playas on the sites identified. Note however, that CRP sites may be underrepresented, as some contracts that were implemented prior to 2000 may have expired at the time of tabulation in 2007 (e.g., Table 2). The dominant program from an area coverage basis on the landscape is CRP (Table 2.) Because CRP has such vast coverage it directly influences $5.4 \%$ of playas throughout the region (ranging from $<1 \%$ in Oklahoma, Nebraska, and New Mexico to $7.5 \%$ in Kansas, and $11.3 \%$ and $11.5 \%$ in Colorado and Texas, respectively). Unfortunately, practices that have been implemented under CRP were not directed at improving or restoring functions of playas (see next section). WRP is essentially only used in association with playas of south-central Nebraska. This program remains underutilized in the High Plains, which contrasts to most other regions across the United States, where WRP is a dominant program in wetland restoration (see others in this issue, e.g., De Steven and Lowrance 2011, Gleason et al. 2011).

One or more of a variety of conservation practices may be applied within each of the conservation programs outlined in the previous paragraph, as well as on an individual site. A conservation practice is defined as "a specific treatment, such as a structural or vegetative measure, or management technique, com-

TABLE 2. Area of lands of active contracts (March 2007) in the USDA's Conservation Reserve Program (CRP) and Wetland Reserve Program (WRP) within the High Plains region of six states.

\begin{tabular}{lcc}
\hline \hline \multicolumn{1}{c}{ State } & $\begin{array}{c}\text { Area enrolled } \\
\text { in CRP (ha) }\end{array}$ & $\begin{array}{c}\text { Area enrolled } \\
\text { in WRP (ha) }\end{array}$ \\
\hline Texas & 1202321.4 & 69.6 \\
New Mexico & 232873.8 & 0.0 \\
Oklahoma & 204928.7 & 62.8 \\
Kansas & 599063.1 & 44.5 \\
Colorado & 513145.4 & 60.7 \\
Nebraska & 236570.8 & 2380.9 \\
\hline
\end{tabular}


monly used to meet specific needs in planning and implementing conservation, for which standards and specifications have been developed" (USDA 2003). Given available data since 2000, there have been at least 65564 occurrences of various conservation practices on the 23085 sites enrolled in a conservation program in the High Plains of Texas, Oklahoma, New Mexico, Kansas, Colorado, and Nebraska. Some available conservation practices specifically relevant to conservation of wetlands include treatments designed to directly conserve, enhance, or manage habitat in and adjacent to wetlands. Only a few occur in the list of the 20 most frequently applied practices, but include fencing off sensitive areas from livestock, restoring and managing rare and declining habitats, range planting, and others (Table 3). However, the remaining relevant wetland practices fall into the bottom tier of the list at a frequency of occurrence of $<0.8 \%$ (e.g., Buffer and Filter Strips, Wetland Restoration, and Wetland Enhancement). As we demonstrated for the dominant programs, these practices are applied much more frequently in other regions of the United States and underutilized in the High Plains.

\section{Conservation Practice Effects on Playa Function}

Because most natural functions of playas are dependent on hydrology, practices that are designed to restore altered hydrology or maintain natural hydrology have the most potential to positively influence natural service delivery (Euliss et al. 2008, Smith et al. 2008). In the High Plains, using conservation practices that mimic or restore hydrological conditions found in native-grassland systems should maximize that potential. Unfortunately, although expenditures for High Plains conservation have been among the top three regions in the nation (USDA 2009), few practices were directed at wetlands as their primary objective. Of the available USDA conservation programs, CRP has likely had the most influence on playas because of establishment in playa catchments on $>2.8$ million ha. However, practices applied with CRP were primarily directed at reducing upland soil erosion and, at least initially, surplus agriculture production. Restoration of playa hydrology was not a consideration during development of CRP contracts. Initial enrollments of cultivated lands into CRP rarely considered playas as separate landforms; planting of exotic perennial CRP grasses in playa hydric soils was an acceptable practice in many states. These exotic grasses are denser and taller than natives and have altered community composition and structure in many playas (e.g., Berthelsen et al. 1989, Smith and Haukos 2002). In addition, because their growth form and residual structure differs from native species, they affect the volume of catchment runoff, the dominant source of water for playas. The amount of water running off exotic (e.g., Old World bluestem [Bothriochloa ischaemum]) CRP catchments into playas is predicted to be much less than native (buffalo grass) grassland
TABLE 3. The 20 most common (by percentage of occurrence) of the 112 conservation practices applied in 89128 total practice occurrences in the High Plains from 2000 to 2006.

\begin{tabular}{lc}
\hline \multicolumn{1}{c}{ Conservation practice and code } & $\begin{array}{c}\text { Occurrence } \\
(\%)\end{array}$ \\
\hline Conservation Crop Rotation (328) & 10.6 \\
Pest Management (595) & 9.6 \\
Upland Wildlife Habitat Management (645) & 9.4 \\
Prescribed Grazing (528) & 7.8 \\
Irrigation Water Management (449) & 5.8 \\
Use Exclusion (472) & 5.6 \\
Residue Management, Seasonal (344) & 4.5 \\
Irrigation System, Sprinkler (442) & 4.3 \\
Residue Management, Mulch Till (345) & 4.2 \\
Nutrient Management (590) & 4.1 \\
Watering Facility (614) & 3.1 \\
Range Planting (550) & 2.9 \\
Windbreak/Shelterbelt Establishment (380) & 2.6 \\
Pipeline (516) & 2.6 \\
Cover Crop (340) & 2.5 \\
Residue Management, No-Till/Strip Till (329) & 1.9 \\
Surface Roughening (609) & 1.8 \\
Conservation Cover (327) & 1.7 \\
Fence (382) & 1.4 \\
Restoration and Management of Rare and & 1.3 \\
Declining Habitats (643) & \\
\hline
\end{tabular}

catchments as determined by the Revised Universal Soil Loss Equation (available online). ${ }^{8}$ Restoration of native grass in catchments of playas remains minimal, despite elevated conservation priorities of wetlands nationwide, and required establishment of native grass and forb species for new CRP contracts under the 1996 and subsequent Farm Bill, and the 2004 approval of Farm Service Agency's Conservation Practice CP23A (Wetland Restoration: Non-Floodplain).

Establishment of buffers of native vegetation around playas with cultivated catchments has excellent potential to reduce sediment loads and assist in the restoration of playa hydrology (Skagen et al. 2008). Buffer effectiveness is further enhanced by implementing other conservation practices (e.g., conservation tillage, balancing input with nutrient requirements for livestock and crops) in the surrounding watershed to diminish soil erosion and associated contaminant runoff (Skagen et al. 2008). Haukos (1995) provided guidance for the establishment of vegetative buffers around playas including (1) a minimum width of $33 \mathrm{~m}$ outward from the edge of hydric soil, increasing with steeper catchment slopes, (2) establishment of a mixture of native grasses and forbs, and (3) periodic ( $\sim 3-5$ years) disturbance and maintenance (e.g., managed grazing, burning, or mowing). Unfortunately, this technique has been seldom applied to playas and direct estimation of its influence on playa hydrology is not fully understood. There are a variety of practices within CRP that can be implemented for establishment of wetland buffers and associated protec-

8 〈http://fargo.nserl.purdue.edu/rusle2_dataweb/RUSLE2_ Index.htm $\rangle$ 


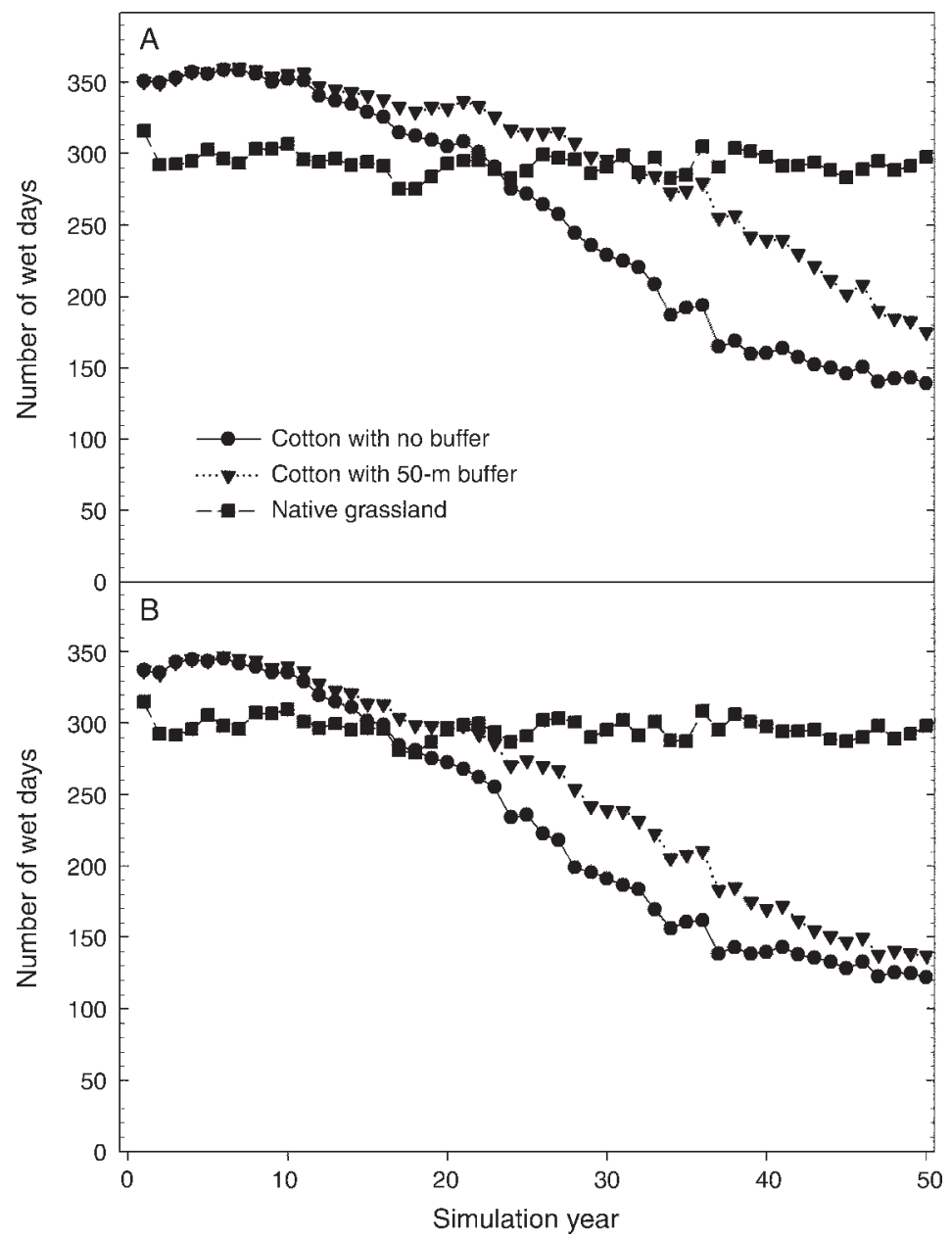

FIG. 2. Simulation results from the Agricultural Policy/Environmental eXtender (APEX; Williams et al. 2004) showing the total number of wet days for playas in native grassland and cotton (with and without 50 -m buffers) catchments with (A) fine- and (B) coarse-textured soil in the Southern High Plains of Texas, USA.

tion of surrounding highly erodible land to minimize the effects of sedimentation.

To further examine buffers we simulated the effects of this practice on hydrology using the Agricultural Policy/ Environmental eXtender (APEX; Williams et al. 2004) to estimate hydroperiod response of playas to alternative agricultural land use practices (Peabody 2005). We modeled total number of wet playa days annually over 50 years for native grassland and cotton agriculture (with and without a 50-m buffer of buffalo grass) in fine- and coarse-textured soil catchments (Fig. 2). Baseline condition for the constructed playa was estimated as the yearly expected outcome derived from 100 50-year stochastic APEX simulations consistent with current weather patterns for Lubbock, Texas, and crop budgets prepared by the Texas Cooperative Extension Service (Williams et al. 2004). The constructed representative playa catchment was 259 ha with a $1 \%$ slope, and the representative playa circular with an area of 6.27 ha and initial depth of $1 \mathrm{~m}$. Over $90 \%$ of all cropland in the study region has a slope $\leq 1 \%$ (Peabody 2005). Runoff from both cultivated-land and nativegrassland watersheds was routed directly into the centrally located playa. Results of the models indicate that a $50-\mathrm{m}$ buffer is protective of cropland playas, but the degree of protection depends on soil texture (Fig. 2). A playa surrounded by cotton growing in fine-textured soil maintained at least the same number of wet days as grassland playas for $\sim 35$ years, compared to 25 years for the same playa in coarse soil. A buffer around crop playas in fine soil increased the number of wet days by as much as 90 (47\% increase) over crop playas without a buffer. This effect was reduced for crop playas in coarse soil, with the buffer providing up to an additional 50 wet days (31\% increase). Although buffer effectiveness is temporary, with total wet days for crop playas with and without buffers converging at the end of 50 years, the buffered crop playa in fine-textured soil still had 36 more wet days $(26 \%)$ than the crop playa without a buffer, but 123 fewer wet days than the grassland playa. The 


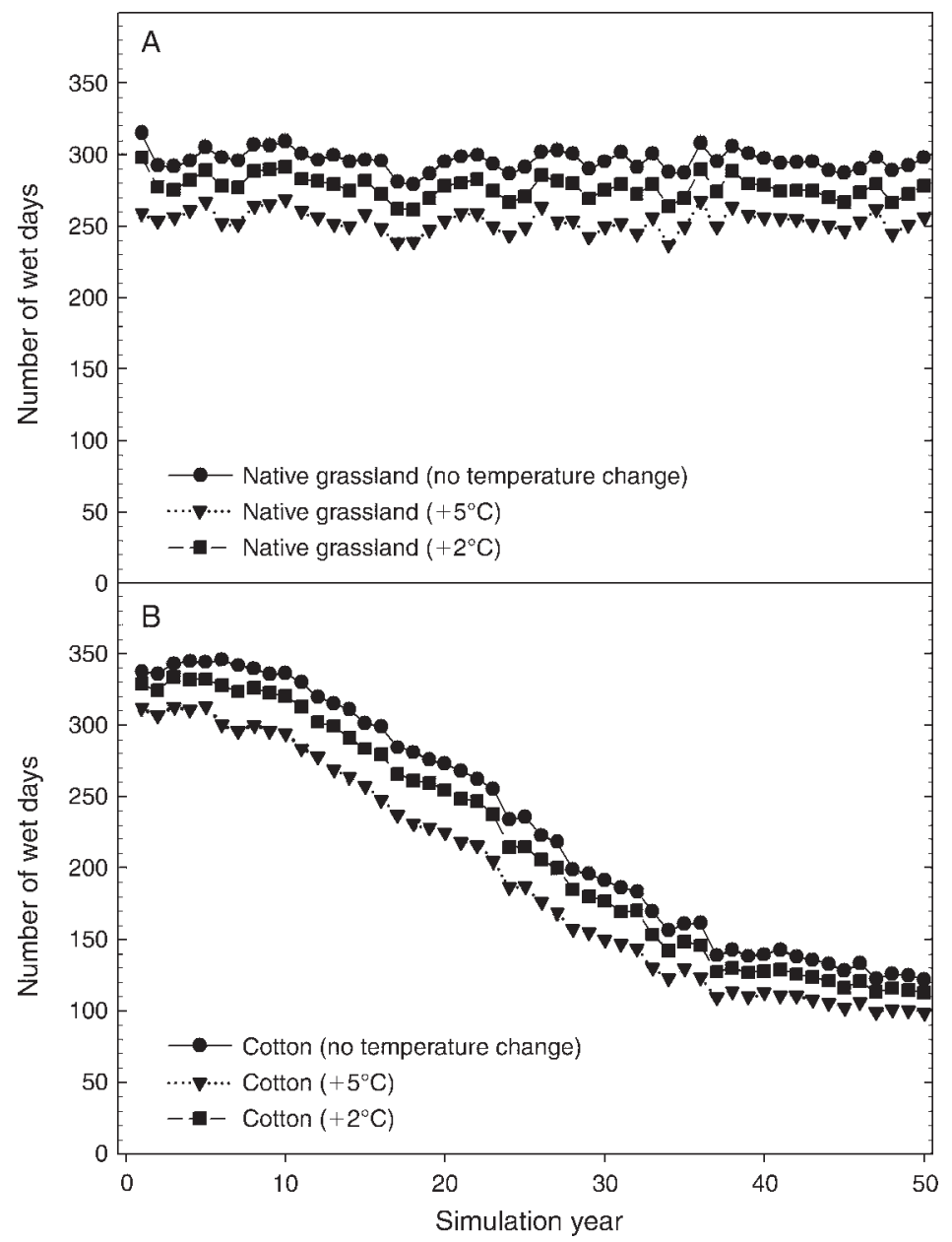

FIG. 3. Simulation results from APEX showing the total number of wet days for playas in (A) native grassland and (B) cotton catchments under three temperature scenarios in the Southern High Plains of Texas.

buffered and non-buffered crop playas in coarse soil differed by only 15 days by year 50 , and had at least 161 fewer wet days than the grassland playa.

We simulated the effect of increased annual temperature on the hydroperiod of playas in native-grassland and cropland watersheds to assess its relative influence compared to cultivation agriculture (Fig. 3). Playas in native grassland immediately demonstrate a consistent drop in the number of wet days, ranging from $\sim 20$ to 40 days per year with a $2^{\circ} \mathrm{C}$ and $5^{\circ} \mathrm{C}$ increase in temperature, respectively. A similar response is observed for cropland playas, but only during the first 30 years of the simulation, after which increased temperature reduced the number of wet days on average by only 12 at $+2^{\circ} \mathrm{C}$ and 28 at $+5^{\circ} \mathrm{C}$. These results highlight the more negative effects of sediment on playa hydrology relative to temperature increases from projected climate change and the need for adequate protection of High Plains' wetland catchments from erosion.

Sediment removal is another practice that has excellent potential to restore playa hydrology.
Sediment removal is an approved WRP wetland restoration technique and has been applied in southcentral Nebraska, but not elsewhere in the region. To a much lesser extent, sediment removal is available as a restoration technique in some of the CRP wetland practices (e.g., CP23A). Sediment removal is ideally done in conjunction with watershed restoration to prevent future sedimentation. WRP allows up to 0.4 ha of catchment to be enrolled as a surrounding vegetated buffer for each 0.4 ha of wetland. These restored catchment areas are thought to provide a buffer that minimizes future accumulation of sediment, but have not been directly evaluated in playas. Sediment removal is expensive, making it imperative to prevent sediment from reaching wetlands and prioritize where sediment removal is applied. Prioritization of playas for conservation can be done by modeling the benefits of restoring a given wetland and examining watershed factors that will result in longevity of benefits (Euliss et al. 2011). In south-central Nebraska, a wetland priority model has been developed using GIS data that includes 
wetland size, distance from other wetlands, density of surrounding wetlands, distance from disturbance factors (e.g., roads), and the proximity of risk factors (e.g., power lines) (Bishop 2004).

\section{Conclusions and Emerging Issues for High Plains Playas}

Although the High Plains is one of the most intensive agricultural regions of the United States, and wetlands are heavily impacted by agriculture throughout the region, few USDA conservation programs and practices have been directly applied to wetlands to improve their associated services. Our review reveals that of all the major wetland regions in the United States, the High Plains has had the fewest applied USDA wetland practices (see other regional reviews in this volume). Because of the semiarid nature of most of the High Plains, ecosystem services provided by playa wetlands are especially unique and vulnerable to degradation (Smith 2003).

The lack of practices directly applied to playas in the High Plains does not suggest that little USDA conservation funding has been expended in the region. The High Plains has the highest density of CRP land in the nation and some of the highest expenditures for conservation practices (USDA 2009). Although CRP land was established without considering wetlands, the vast majority of CRP directly affects playas because of extensive occurrence in playa catchments and influences on runoff volume, the most influential water budget metric in these wetlands. Because hydrology influences most functions of playas, CRP has an important influence on playa services. However, most CRP contracts were established using dense exotic perennial grasses, which effectively reduces erosion but limits runoff volume relative to native grass, negatively influencing natural playa hydrology. Participation in USDA programs by private landowners in the High Plains is nearly universal, and the potential for restoration of playa services is extensive, but only if WRP and its associated practices are promoted and playas are considered an integral part of CRP contracts.

If this policy change occurs, USDA conservation practices can have a substantial positive impact on delivery of playa services in a short period of time, as has been demonstrated in the upper Midwest (Fennessy and Craft 2011). Because sediment is the dominant threat to playa hydrology, two practices (establishment of buffers and sediment removal) show the most promise for restoring ecosystem function and related services. As demonstrated, native-grass buffers can protect playas from future sediment deposition and sediment removal can restore hydroperiod.

Several emerging issues have the potential to influence service delivery by playas. Alternative-energy development, especially the recent rapid growth in biofuels (e.g., ethanol and soy diesel; De La Torre Ugarte et al. 2006, Renewable Fuels Association 2007), are having a major impact on playa wetlands and their surrounding watersheds. Higher prices for corn and soybeans as a result of biofuel demand are playing a substantial role in influencing land use decisions. The primary impact is increased pressure to plant corn on areas currently in other crops, grassland, or enrolled in conservation programs. There is increased interest in draining wetlands, cultivation of remaining grasslands, and removing installed conservation practices to increase crop production. Alternatively, there has been interest in using plant cellulose (e.g., stems and leaves) to make ethanol (Tilman et al. 2006). If this proves to be economically viable, a potential benefit would be keeping areas in grassland and possibly in some areas converting cropland to grassland.

Most playa wetlands are isolated and no longer protected under the Clean Water Act (Haukos and Smith 2003). However, farms in the High Plains that participate in the USDA Farm Bill programs are subject to compliance under Swampbuster provisions as developed in the 1985 Food Security Act and maintained through subsequent Farm Bills. Swampbuster provisions deny federal farm program benefits to producers who have altered wetlands after 23 December 1985 for the purpose of producing a commodity crop (Haukos and Smith 2003). Enforcement of these provisions may help to reduce playa conversions to cropland. A potential obstacle to enforcement of Swampbuster provisions in the High Plains is the current effort to reclassify soils in Texas, New Mexico, and Oklahoma. Counties for which reclassification is complete have reduced the number and area of playas represented by a hydric soil compared to historical conditions. Initial speculation to explain these reductions center on the likelihood that reclassification for playas with cultivated catchments is occurring based on accumulated sediment rather than the underlying historical hydric soil. Without the obvious presence of a hydric soil, it would be impossible for a playa to be declared a jurisdictional wetland under provisions of the current Farm Bill and make it ineligible for participation in USDA wetland conservation programs. Thus, widespread reclassification of soils will potentially reduce opportunities for restoration of playa functions.

Because the annual withdrawal of water from the Ogallala Aquifer greatly exceeds recharge, aquifer depletion is a major concern in the region (Wood et al. 1997). Continued loss and degradation of playas will directly impact the future ability of landowners to irrigate their crops. As the aquifer declines and playas cease to function, irrigated agriculture will be forced to change crops (potentially genetic engineered to reduce water needs), accept dryland-farming practices, or revert cultivated areas back to grassland to support livestock grazing. Such changes, which appear inevitable at the current unsustainable rate of aquifer withdrawal, will greatly impact the landscape and require leadership in 
the application of conservation practices to ensure the continued viability of High Plains' wetlands.

\section{ACKNOWLEDGMENTS}

We thank the Natural Resources Conservation Service through CEAP-Wetlands for financial assistance. Oklahoma State University, the U.S. Fish and Wildlife Service, and the Nebraska Game and Parks Commission also provided assistance. Andy Bishop provided GIS data and interpretation. Tim McCoy, Jill Baron, Diane Eckles, Randy Stutheit, and two anonymous referees provided helpful comments on the manuscript. Mindy Rice provided mapping and GIS expertise. Partial funding was provided by the U.S. EPA, project R82964101-0 and the National Science Foundation (DMS number 0201105).

\section{Literature Cited}

Anderson, J. T., and L. M. Smith. 2002. The effect of flooding regimes on decomposition of Polygonum pensylvanicum in playa wetlands (Southern Great Plains, USA). Aquatic Botany 74:97-108.

Bergan, J. F., and L. M. Smith. 1993. Survival rates of female mallards wintering in the Playa Lakes Region. Journal of Wildlife Management 57:570-577.

Berthelsen, P. S., L. M. Smith, and C. Coffman. 1989. CRP land and game bird production in the Texas High Plains. Journal of Soil and Water Conservation 44:504-507.

Bishop, A. 2004. Rainwater Basin Joint Venture waterfowl habitat use model. Internal report. U.S. Fish and Wildlife Service, Grand Island, Nebraska, USA.

Bolen, E. G., L. M. Smith, and H. L. Schramm, Jr. 1989. Playa lakes: prairie wetlands of the Southern High Plains. BioScience 39:615-623.

Cowardin, L. M., V. Carter, F. C. Golet, and E. T. LaRoe. 1979. Classification of wetlands and deepwater habitats of the United States. U.S. Fish and Wildlife Service, Washington, D.C., USA.

De La Torre Ugarte, D., B. English, K. Jensen, C. Hellwinckel, J. Menard, and B. Wilson. 2006. Economic and agricultural impacts of ethanol and biodiesel expansion. Agricultural Economics Study Report. University of Tennessee, Knoxville, Tennessee, USA.

De Steven, D., and R. Lowrance. 2011. Agricultural conservation practices and wetland ecosystem services in the wetlandrich Piedmont-Coastal Plain region. Ecological Applications 21(Supplement):S3-S17.

Eckles, S. D. 2011. Linking science, policy, and management to conserve wetlands on agricultural landscapes. Ecological Applications 21(Supplement):S1-S2.

Euliss, N. H., Jr., L. M. Smith, S. Liu, W. G. Duffy, S. P. Faulkner, R. A. Gleason, and S. D. Eckles. 2011. Integrating estimates of ecosystem services from conservation programs and practices into models for decision makers. Ecological Applications 21(Supplement):S128-S134.

Euliss, N. H., Jr., L. M. Smith, D. A. Wilcox, and B. A. Browne. 2008. Linking ecological processes with wetland management goals: charting a course for a sustainable future. Wetlands 28:553-562.

Fennessy, S., and C. Craft. 2011. Agricultural conservation practices increase wetland ecosystem services in the Glaciated Interior Plains. Ecological Applications 21(Supplement):S49S64.

Ghioca, D. M., and L. M. Smith. 2008. Population structure of Ambystoma tigrinum mavortium in playa wetlands: landuse influence and variations in polymorphism. Copeia 2008:286293.

Ghioca-Robrecht, D. M., and L. M. Smith. 2008. Feeding ecology of polymorphic larval tiger salamanders in playas of the Southern Great Plains. Canadian Journal of Zoology 86: $554-563$.
Ghioca-Robrecht, D. M., L. M. Smith, and L. D. Densmore. 2009. Ecological correlates of trophic polyphenism in spadefoot tadpoles inhabiting playas. Canadian Journal of Zoology 87:229-238.

Gleason, R. A., N. H. Euliss, Jr., B. A. Tangen, M. K. Laubhan, and B. A. Browne. 2011. USDA conservation program and practice effects on wetland ecosystem services in the Prairie Pothole Region. Ecological Applications 21(Supplement):S65-S81.

Gray, M. J., and L. M. Smith. 2005. Influence of land use on postmetamorphic body size of playa lake amphibians. Journal of Wildlife Management 69:515-524.

Gray, M. J., L. M. Smith, and R. Brenes. 2004. Effects of agricultural cultivation on demographics of Southern High Plains amphibians. Conservation Biology 18:1368-1377.

Grubb, H. W., and D. L. Parks. 1968. Multipurpose benefits and costs of modifying playa lakes of the Texas High Plains. Special Report 6. International Center for Arid and SemiArid Land Studies, Lubbock, Texas, USA.

Grubb, H. W., D. L. Parks, and G. W. Sciple. 1968. Benefits and costs of modifying playa lakes to reduce encephalitis in the Texas High Plains. Department of Agricultural Economics, Texas Tech University, Lubbock, Texas, USA.

Gustavson, T. C., V. T. Holliday, and S. D. Hovorka. 1995. Origin and development of playa basins, sources of recharge to the Ogallala Aquifer, Southern High Plains, Texas and New Mexico. Report Investigations 229. Bureau of Economic Geology, Austin, Texas, USA.

Guthery, F. S., F. C. Bryant, B. Kramer, A. Stocker, and M. Dvoracek. 1981. Playa assessment study. U.S. Water and Power Resources Service, Amarillo, Texas, USA.

Haukos, D. A. 1994. Management of playas for wildlife enhancement. Pages 267-276 in L. V. Urban and A. W. Wyatt, editors. Proceedings of playa basin symposium. Water Resources Center, Texas Tech University, Lubbock, Texas, USA

Haukos, D. A. 1995. Management of playa wetlands impacted by agriculture. Pages $110-113$ in S. O. Foster, S. Pas, S. Rush, and O. Thorne, editors. Proceedings of the Symposium on issues and technology in the management of impacted wildlife. Glenwood Springs, Colorado, USA.

Haukos, D. A., M. R. Miller, D. L. Orthmeyer, J. Y. Takekawa, J. P. Fleskes, M. L. Casazza, W. M. Perry, and J. A. Moon. 2006. Spring migration of northern pintails from Texas and New Mexico, USA. Waterbirds 29:127-136.

Haukos, D. A., and L. M. Smith. 1994. The importance of playa wetlands to biodiversity of the Southern High Plains. Landscape and Urban Planning 28:83-98.

Haukos, D. A., and L. M. Smith. 2003. Past and future impacts of wetland regulations on playa ecology in the Southern Great Plains. Wetlands 23:577-589.

Haukos, D. A., and L. M. Smith. 2004. Plant communities of playa wetlands in the Southern Great Plains. Special Publication 47. Museum of Texas Tech University, Lubbock, Texas, USA.

Haukos, D. A., and L. M. Smith. 2006. Effects of soil water on seed production and photosynthesis of pink smartweed (Polygonum pensylvanicum L.) in playa wetlands. Wetlands 26:265-270.

Irwin, R. J., P. J. Connor, D. Baker, and C. Littlefield. 1996. Playa lakes of the Texas High Plains: a contaminants survey and assessment of biological integrity. Ecological Services, U.S. Fish and Wildlife Service, U.S. Department of Interior, Arlington, Texas, USA.

Küchler, A. W. 1975. Potential natural vegetation of the conterminous United States. Second edition. American Geographical Society, New York, New York, USA.

Kuzila, M. S. 1994. Inherited morphologies of two large basins in Clay County, Nebraska. Great Plains Research 4:51-63.

LaGrange, T. G. 2005. A guide to Nebraska's wetlands and their conservation needs. Second edition. Nebraska Game and Parks Commission, Lincoln, Nebraska, USA. 
Luo, H. R. 1994. Effects of land use on sediment deposition in playas. Thesis. Texas Tech University, Lubbock, Texas, USA.

Luo, H. R., L. M. Smith, B. L. Allen, and D. A. Haukos. 1997. Effects of sedimentation on playa wetland volume. Ecological Applications 7:247-252.

Luo, H. R., L. M. Smith, D. A. Haukos, and B. L. Allen. 1999. Sources of recently deposited sediments in playa wetlands. Wetlands 19:176-181.

McMurry, S. M., L. M. Smith, K. D. Dupler, and M. Guitierrez. 2009. Influence of land use on body size and splenic cellularity in wetland breeding Spea spp. Journal of Herpetology 43:421-430.

Moon, J. A., and D. A. Haukos. 2006. Survival of female northern pintails wintering in the Playa Lakes Region of northwestern Texas. Journal of Wildlife Management 70: $777-783$.

Nativ, R., and R. Riggio. 1989. Meteorlogic and isotopic characteristics of precipitation events with implications for ground-water recharge, Southern High Plains. Atmospheric Science 23:51-82.

Nebraska Department of Agriculture. 2006. Nebraska agriculture fact card. Nebraska Department of Agriculture, Lincoln, Nebraska, USA. 〈http://www.agr.state.ne.us/facts.pdf $\rangle$

NRC [National Research Council]. 1995. Wetlands characteristics and boundaries. National Academy Press, Washington, D.C., USA.

Osterkamp, W. R., and W. W. Wood. 1987. Playa-lake basins on the Southern High Plains of Texas and New Mexico, Part 1. Hydrologic, geomorphic, and geologic evidence of their development. Geological Society of America Bulletin 99:215223.

Peabody, P. 2005. Agricultural cost of maintaining playa lake hydroperiod to preserve playa lake ecosystems in the Texas High Plains. Thesis. Texas Tech University, Lubbock, Texas, USA.

Reeves, C. C., Jr., and J. A. Reeves. 1996. The Ogallala Aquifer (of the Southern High Plains). Estacado Books, Lubbock, Texas, USA.

Renewable Fuels Association. 2007. Historic U.S. fuel ethanol production. Renewable Fuels Association, Washington, D.C., USA. 〈http://www.ethanolrfa.org/pages/statistics\#A〉

Sabin, T. J., and V. T. Holliday. 1995. Playas and lunettes on the Southern High Plains: morphometric and spatial relationships. Annals of the Association of American Geographers 85:286-305.

Samson, F. B., and F. L. Knopf. 1994. Prairie conservation in North America. BioScience 44:418-421.

Skagen, S. K., C. P. Melcher, and D. A. Haukos. 2008. Reducing sedimentation of depressional wetlands in agricultural landscapes. Wetlands 28:594-604.

Smith, L. M. 1988. Lack of vertebrate herbivory in playa wetlands. Wetlands 8:193-197.

Smith, L. M. 2003. Playas of the Great Plains. University of Texas Press, Austin, Texas, USA.

Smith, L. M., N. H. Euliss, Jr., D. A. Wilcox, and M. M. Brinson. 2008. Application of a geomorphic and temporal perspective to wetland management in North America. Wetlands 28:563-577.
Smith, L. M., and D. A. Haukos. 2002. Floral diversity in relation to playa wetland area and watershed disturbance. Conservation Biology 16:964-974.

Stone, W. J. 1990. Natural recharge of the Ogallala Aquifer through playas and other non-stream settings. Pages 180-192 in T. C. Gustavson, editor. Geologic framework and regional hydrology: Upper Cenozoic Blackwater Draw Formations, Great Plains. Bureau of Economic Geology, Austin, Texas, USA.

Thurman, E. M., K. C. Bastian, and T. Mollhagen. 2000. Occurrence of cotton herbicides and insecticides in playa lakes of the High Plains of west Texas. Science of the Total Environment 248:189-200.

Tilman, D., J. Hill, and C. Lehman. 2006. Carbon-negative biofuels from low-input high-diversity grassland biomass. Science 314:1598-1600.

Tsai, J.-S. 2007. Local and landscape factor influences on avian community composition in playas of the Southern High Plains. Dissertation. Texas Tech University, Lubbock, Texas, USA.

Tsai, J.-S., L. S. Venne, S. T. McMurry, and L. M. Smith. 2007. Influences of landuse and wetland characteristics on water loss rates and hydroperiods of playas in the Southern High Plains, U.S.A. Wetlands 27:683-692.

USDA [U.S. Department of Agriculture]. 2003. National planning procedures handbook. 180-VI. Amendment 4. USDA, Beltsville, Maryland, USA.

USDA [U.S. Department of Agriculture]. 2009. 2007 census of agriculture. Volume 1. U.S. summary and state reports. Geographic area series. Part 51. USDA, National Agricultural Statistics Service, Washington, D.C., USA.

U.S. Department of Interior. 1982. Llano Estacado playa lake water resources study. United States Bureau of Reclamation, Southwest Region, Amarillo, Texas, USA.

Venne, L. S., T. A. Anderson, B. Zhang, L. M. Smith, and S. T. McMurry. 2008. Organochlorine pesticide concentrations in sediment and amphibian tissue in playa wetlands in the Southern High Plains, USA. Bulletin of Environmental Contamination and Toxicology 80:497-501.

Venne, L. S., G. P. Cobb, G. Coimbatore, L. M. Smith, and S. T. McMurry. 2006. Influence of land use on metal concentrations in playa sediments and amphibians in the Southern High Plains. Environmental Pollution 144:112-118.

Williams, J. R., E. Wang, A. Meinardus, and W. L. Harmon. 2004. APEX users guide. Version 1310. USDA, Blackland Research and Extension Center, Temple, Texas, USA.

Wood, W. W., and W. R. Osterkamp. 1987. Playa-lake basins on the Southern High Plains of Texas and New Mexico. Part 2. A hydrologic model and mass-balance arguments for their development. Geological Society of America Bulletin 99:224230.

Wood, W. W., K. A. Rainwater, and D. B. Thompson. 1997. Quantifying macropore recharge: examples from a semi-arid area. Ground Water 35:1097-1106.

Wright, H. A., and A. W. Bailey. 1982. Fire ecology: United States and southern Canada. John Wiley and Sons, New York, New York, USA. 